\title{
Marine late Saalian to Eemian environments and climatic variability in the Danish shelf area
}

\author{
Marit-Solveig Seidenkrantz $^{1,2,}$ Karen Luise Knudsen ${ }^{2} \&$ Peter Kristensen $^{2}$ \\ 1 Corresponding author \\ 2 Department of Earth Sciences, University of Aarhus, DK-8000 ÅRHUS C, Denmark
}

Received: 22 January 1999; accepted in revised form: 10 March 2000

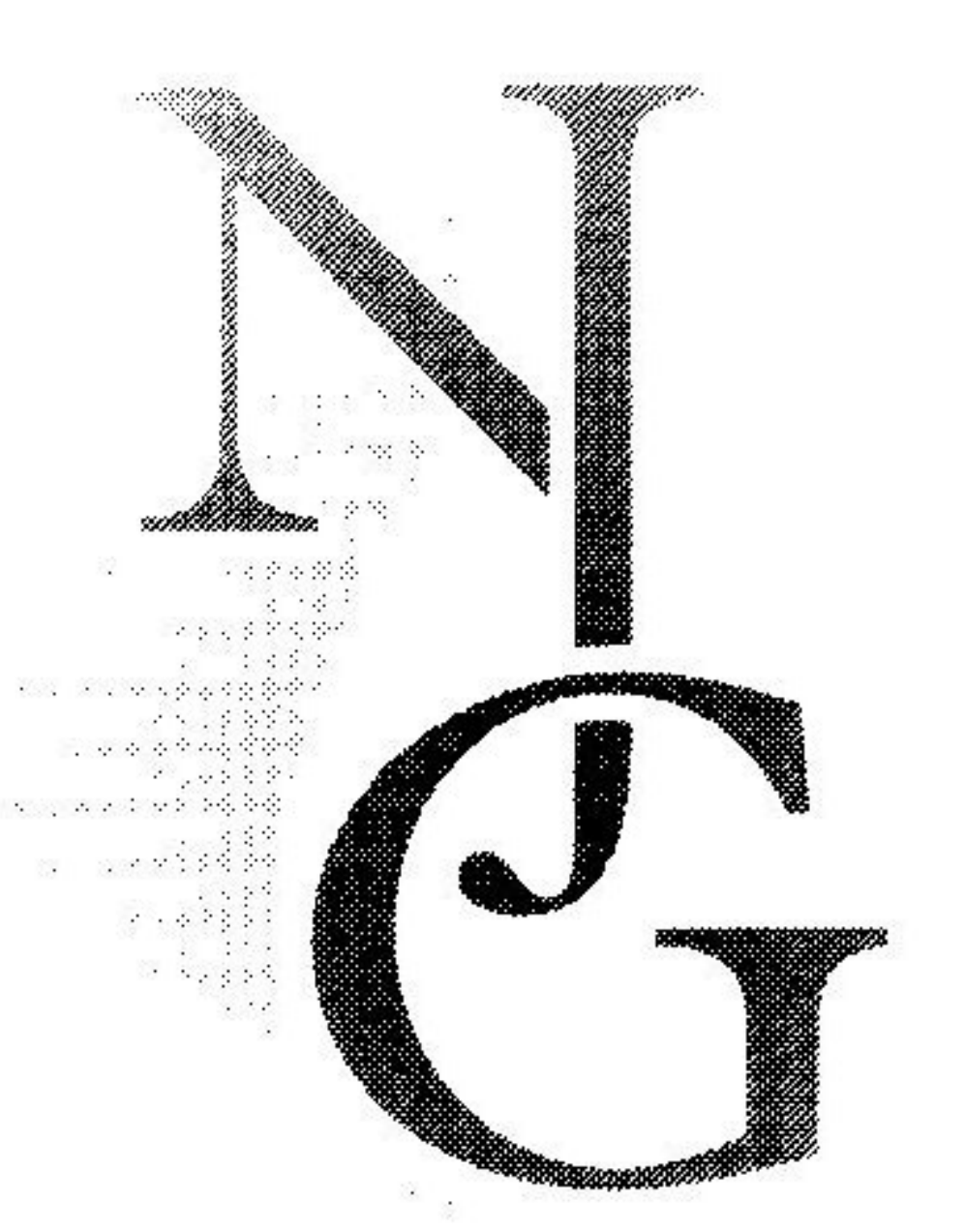

\begin{abstract}
The marine Eemian (marine oxygen-isotope substage 5e: MIS 5e) is represented by shallow-water deposits in southern and western Denmark, while relatively deep-water environments occurred to the north and north-east, where complete interglacial successions seem to be present. We present an overview of the marine Eemian deposits in Denmark, and discuss in more detail indications of climate variability, both for the late Saalian and within the Eemian.
\end{abstract}

Keywords: coastline; Eemian; Foraminifera; marine environment; paleogeography; paleotemperature; stable isotopes

\section{Introduction}

The Eemian (MIS 5e) was a period of higher global sea level (Chappell \& Shackleton, 1986; Shackleton, 1987; Gallup et al., 1994) and generally higher temperatures than at present (CPM, 1984; Sejrup \& Larsen, 1991). A climatically unstable Eemian was first suggested on the basis of conflicting ice-core records (Dansgaard et al., 1993; GRIP Members, 1993; McManus et al., 1994; Johnsen et al., 1995). Climatic instability has, however, been supported by marine Eemian records both from the Danish area (Seidenkrantz et al., 1995; Seidenkrantz \& Knudsen, 1997; Glaister \& Gibbard, 1998; Kristensen et al., 1998) and in the northern North Atlantic (Fronval \& Jansen, 1996, 1997; Adkins et al., 1997; Fronval et al., 1998). A significantly more unstable climate during the Eemian than during the Holocene has also been interpreted from European pollen records (among others, Field et al., 1994), and recently even from lake-level interpretations in the Hollerup lacustrine basin (Fig. 1) in Jutland (Denmark) (Björck et al., 2000).
The present contribution provides an overview of the marine Eemian (here correlated with MIS 5e) environment, and evidence for Eemian climate fluctuations in Denmark, with special emphasis on the deeper-water deposits in the northern and north-eastern part of the area. A possible correlation of the Eemian interglacial in NW European shelf records with the Nordic Sea stratigraphy of Fronval \& Jansen (1996, 1997) and Fronval et al. (1988) is suggested by Knudsen et al. (in press).

\section{Eemian palaeogeography}

The suggested Eemian distribution of land and sea in Denmark is shown in Figure 1. The higher global sea level during the Eemian, as well as the isostatic depression after the extensive Saalian glaciation (cf. Zagwijn, 1986), permitted a widespread ingression over coastal areas in NW Europe (Behre et al., 1979; Kosack \& Lange, 1985; Penney, 1989). The Holocene inundations after the Weichselian glaciation was much less extensive (see, among others, Krog, 1979).

The marine Eemian in Denmark was deposited in 


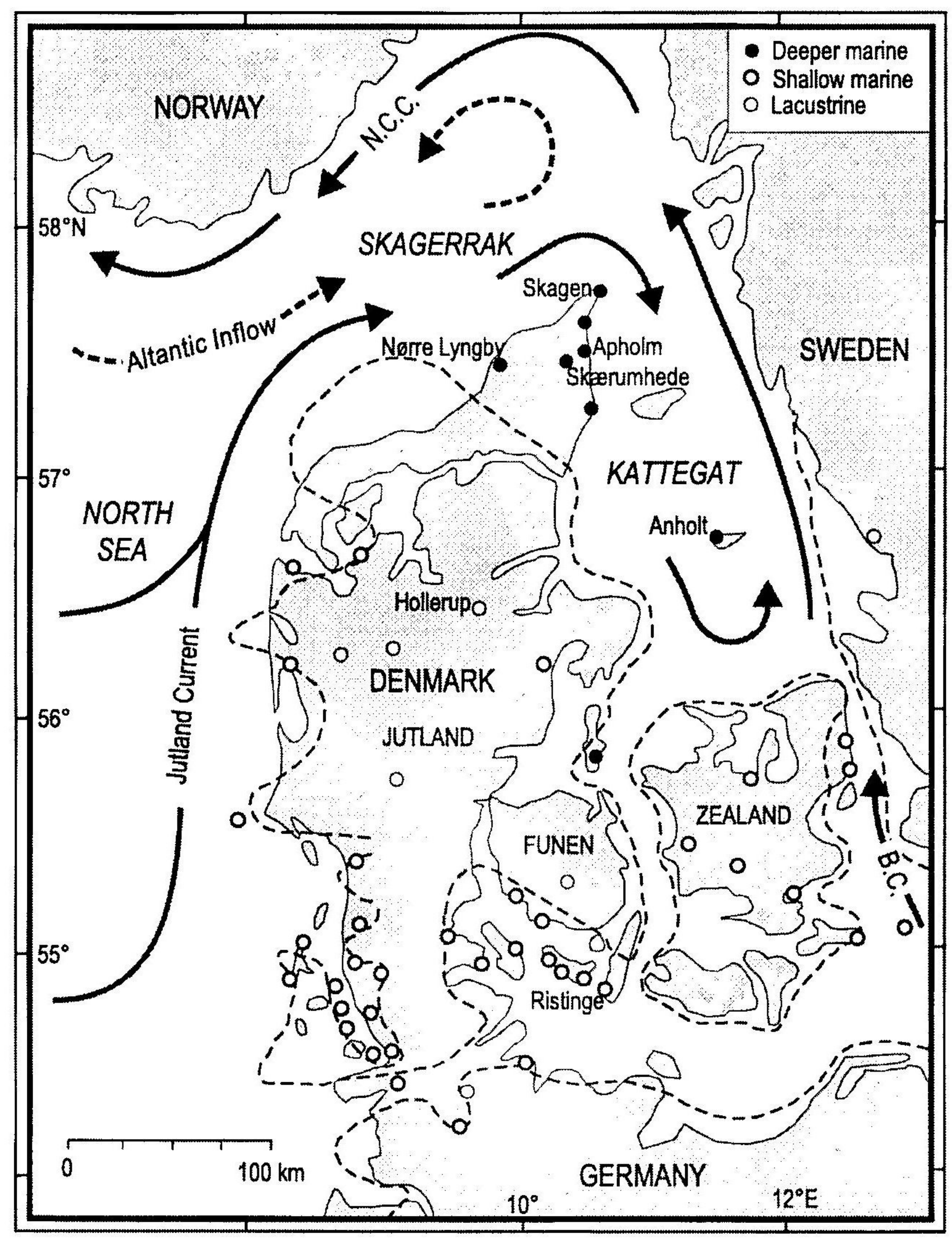

Fig. 1. The Eemian palaeogeography of Denmark. The broken line shows the suggested maximum extent of the Eemian transgression. The most important marine and lacustrine sites are shown as circles. Many of the shallow-marine sediments at sites in the western Baltic area are glacially dislocated, and the exact location of the Eemian coastline is uncertain. The present surface (solid lines) and bottom (broken lines) current systems (after Svansson, 1975) are indicated.

B.C. $=$ Baltic Current; N.C.C. $=$ Norwegian Coastal Current. See also Figure 6.

two different types of environment. In western and southern Denmark (Fig. 1), the Eemian is represented by shallow-marine sediments deposited at water depths of less than $40 \mathrm{~m}$. These were formed in innershelf, tidal-flat and fjord/sound environments. An open sound across northern Germany connected the shallow-water areas of the North Sea with those of the western Baltic Sea during part of the Eemian (Fig. 1; see also Kosack \& Lange, 1985).

To the north, a deep, complex, tectonically determined and glacially eroded trench, the Kattegat Depression, extended from the present Skagerrak across northern Jutland and into the Kattegat (Fig. 1) (Lykke-Andersen, 1987; Lykke-Andersen et al., 1993; Kristensen et al., 1998). This trench was presumably connected to the shallow Baltic Sea by narrow seaways through the Danish Belts on both sides of Zealand (Fig. 1) during part of the Eemian, although no Eemian deposits have yet been located at the bottom of these sounds. The marine Eemian deposits present on the island of Zealand all seem to have been glacially dislocated.

The Baltic Sea was presumably further connected to the Arctic Ocean through the White Sea, at least during part of the Eemian (Zans, 1936; Forström et al., 1988; Raukas, 1991; Seidenkrantz \& Knudsen, 1997; Björck et al., 2000; Kristensen et al., in press). Details of the timing of this possible connection is, however, a subject of further studies.

\section{South-Western Denmark and the Western Baltic}

Eemian shallow-water deposits are usually found to be dislocated by glaciers in the western Baltic area (Fig. 1; see also Konradi, 1976; Kristensen et al., in press), while they occur in situ to the west of the maximum extent of the Weichselian ice sheet (see, among others, Nordmann, 1928; Penney, 1989). This shallow-water facies of the marine Eemian continues towards the south into northern Germany (Knudsen 1985; Kosack \& Lange, 1985) and the Netherlands (Van Voorthuysen, 1957).

A characteristic feature of the Eemian foraminiferal assemblages throughout NW Europe is the immigration of certain species of more southerly affinity. Typical lusitanian (warm temperate) species in the interglacial shallow-water assemblages both in SW Denmark and in the western Baltic area are Elphidium translucens Natland and Elphidium lidoense Cushman (Penney, 1989; Konradi, 1976; Kristensen et al., in press). There is, however, also a certain content of species that live in arctic waters today, such as Buccella frigida (Cushman) and Haynesina orbiculare (Bra$\mathrm{dy}$ ), and in the western Baltic area Haynesina nivea (Lafrenz) as well. The ecological implications of this mixed type of assemblage is still unclear, but it might be a result of a seasonally strong stratification of the water column creating cold bottom waters (Kristensen et al., in press).

Studies of foraminifers and pollen from the Eemian at Ristinge Klint (Fig. 1) show that marine conditions were initiated at about 300-365 years after the beginning of the interglacial in this part of the Baltic area (Kristensen et al., in press). This seems to be slightly later than the first inundation through Northern Germany (Behre et al., 1979; Kosack \& Lange, 1985) but earlier than any known marine deposition in the westernmost part of the Baltic (Jessen \& Milthers, 1928). In the easternmost Baltic, however, marine conditions appears to have been established even earlier than in the western Baltic and northern Germany (see Raukas, 1991; Kristensen et al., in press). It is not possible at present to determine whether the connection from the open sea into the Baltic was first es- 
tablished from the west through northern Germany or from the White Sea in the north-east.

A change to higher salinity assemblages at about 650 years after the beginning of the Eemian at Ristinge may point to an opening of the Danish Belts at the time. Salinities higher than at present in the Baltic persisted for at least 3000 years after the opening of the straits (Kristensen et al., in press).

A multi-stratigraphic study of lake deposits at Hollerup (Fig. 1) suggests a highly maritime climate in Denmark during the early phase of the Eemian and during the Eemian climatic optimum (in total about 3000 years, Björck et al., 2000). They considered this to be a result of extensive transgressions in the region during a high relative sea level and an open-marine connection to the White Sea through the Baltic. Zagwijn (1996) also considered the presence of free interchange of sea water between the Atlantic and the Arctic Ocean during the Eemian to be responsible for the pronounced maritime climate prevailing in western and central Europe. According to him, however, this maritime climate was not initiated until about 2000 years after the start of the Eemian, and it remained throughout the interglacial.

\section{Northern Denmark}

Foraminiferal assemblages show that part of the Kattegat Depression had a water depth of $100-300 \mathrm{~m}$ during the Eemian (Knudsen, 1992; Seidenkrantz, 1993a; Seidenkrantz \& Knudsen, 1997; Kristensen et al., 1998). The southern slope of this deep trench seems to have been relatively steep, as no shallow-water deposits have yet been recorded at its southern margins. The northern margins, however, have not yet been identified. The trench can be regarded as a southern extension of the modern Norwegian Trench. It was already flooded during the late Saalian, and it remained a marine basin that was filled with marine sediments during the Eemian and part of the Weichselian (Lykke-Andersen et al., 1993).

The general Eemian palaeohydrography in the Skagerrak/Kattegat area is believed to have been relatively similar to that at present. Today, the surface waters of the Skagerrak and the Kattegat are characterised by an inflow of Atlantic water into the North Sea north of Scotland (Svansson, 1975). This water mixes with a minor inflow through the English Channel and with fresh water from the European rivers, before it travels north along the west coast of Jutland (the Jutland Current, Fig. 1) and into the Skagerrak and Kattegat. In the Kattegat, this current is mixed with low-saline surface water travelling from the Baltic Sea (the Baltic Current, Fig. 1), whereupon it exits the area along the Norwegian coast (the Norwegian Coastal Current, Fig. 1). The bottom water of the Skagerrak and the Kattegat is influenced by saline water from the Atlantic entering trough the Norwegian Trench as a counter current (Atlantic Inflow, Fig. 1) to the outflowing low-salinity surface water and causing the formation of a halocline in the Kattegat.

Studies of thick marine Eemian deposits from the deep Kattegat Depression in Northern Denmark have shown that this area had high sedimentation rates during the interglacial. Foraminifera from the Skærumhede I borehole (Fig. 1; cored in 1905) (Knudsen \& Lykke-Andersen, 1982) thus revealed a $40 \mathrm{~m}$ thick Eemian marine sequence, that had been deposited at a water depth in excess of $100 \mathrm{~m}$. Similar deep- water foraminiferal assemblages were found in a $50-\mathrm{m}$ thick Eemian sequence in the Apholm borehole (Fig. 1; cored in 1941) (Knudsen, 1984). Although sample resolution and sample quality in the Apholm core were much improved compared to the Skærumhede I borehole, the sample intervals were still relatively large at some levels.

The Eemian assemblages at Skærumhede and Apholm indicate interglacial conditions that were warmer than in the same area today (Knudsen \& Lykke-Andersen, 1982; Knudsen, 1992). Thus, the diagnostic species, Quinqueloculina padana Perconig, appears to be restricted at present to the Mediterranean, where it lives at water depths of at least $100 \mathrm{~m}$.

The distribution of arctic, transitional and boreal/ lusitanean species through the Eemian and early Weichselian in the Apholm core is shown in Figure 2. An increase in shallow-water, low-salinity species in the late Eemian (increase in Elphidium spp.) is seen at both Skærumhede and Apholm. This presumably indicates a lowering of the sea level prior to the abrupt temperature decrease and sea-level drop at the termination of the Eemian (Knudsen, 1992). An apparent gradual decrease in temperature through the early Weichselian (MIS 5a-d) in the Apholm core is thought to result from the large sampling intervals (Fig. 2).

In order to obtain a high-resolution study of the Eemian in the region, boreholes have been drilled on the island of Anholt, at Skagen and at Nørre Lyngby (Fig. 1). The Anholt record has been amino-acid dated as Eemian interglacial (Seidenkrantz, 1993a), but part of the Eemian record is missing at the site. Recent optical luminescence datings support an Eemian age of the interglacial records at Anholt and Skagen, and also at Nørre Lyngby (Andrew Murray, pers. comm., 1999); this age has sometimes been questioned for the latter two sites on the basis of conflicting amino-acid results (Sejrup \& Knudsen, 1999). It 


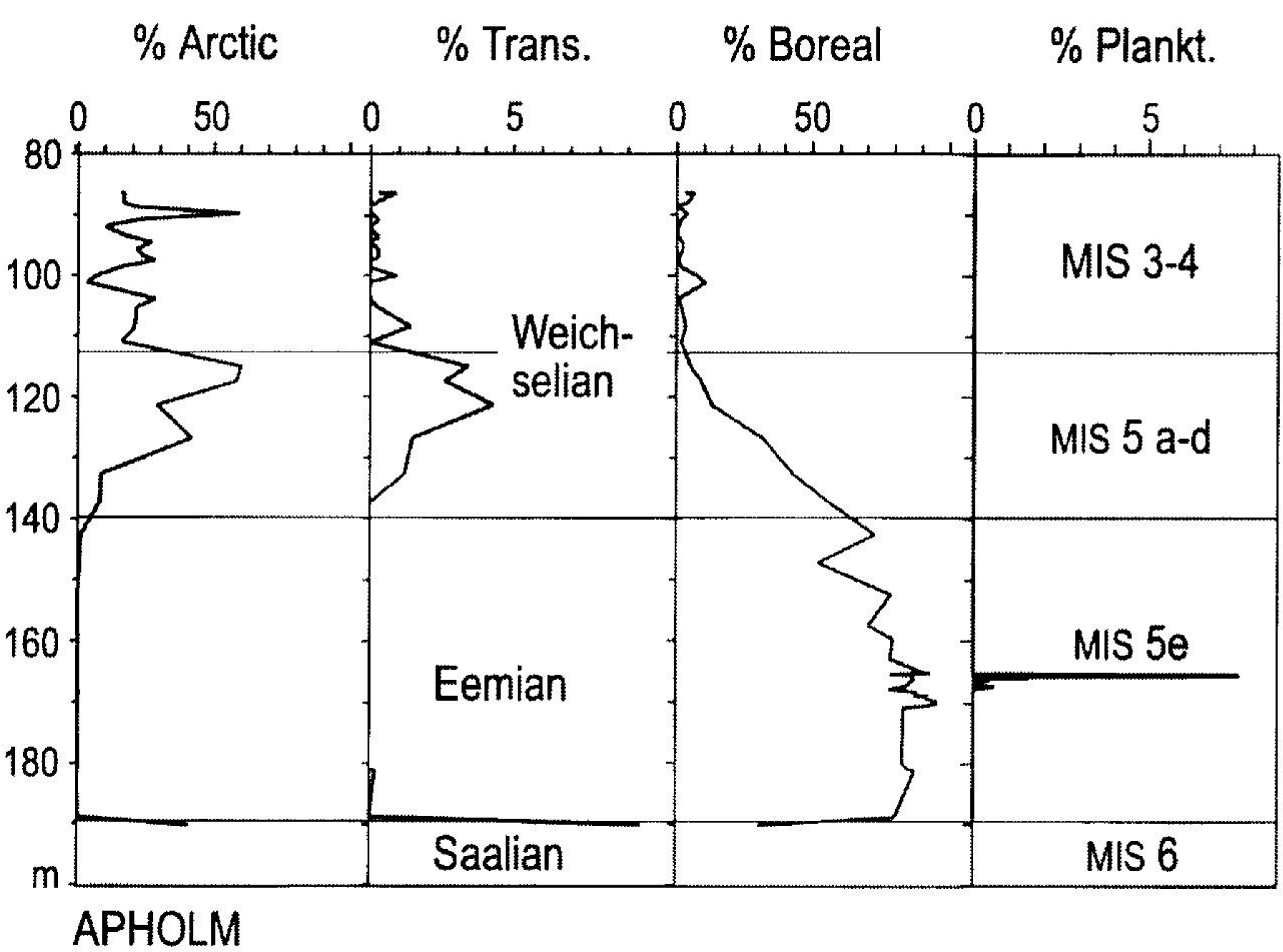

Fig. 2. Late Saalian, Eemian and early Weichselian foraminiferal data from Apholm. 'Arctic', 'transitional' and 'boreal' (including lusitanian) benthic species are grouped according to Seidenkrantz \& Knudsen (1997) and shown as percentages of the total benthic foraminiferal fauna. Cosmopolitan species and species with uncertain environmental requirements are not included. A significant member of this 'indifferent' group is Elphidium excavatum s.l. (Terquem) because the arctic form clavata and the boreal form selseyensis were not counted separately.

Trans. $=$ transitional benthic species; Plankt. $=$ planktonic foraminifers.

is not yet clear whether the entire Eemian is actually present at Skagen and Nørre Lyngby, but this presentation assumes that the records are at least almost complete.

\section{The late Saalian Zeifen-Kattegat oscillation}

As the Saalian ice sheet retreated, the late Saalian sea penetrated from the North Atlantic through the Norwegian Trench into the deep Kattegat Depression. At Anholt (Fig.1), marine sediments directly overlie a
Saalian till and it appears that the complete late Saalian deglaciation is represented by a marine succession (late MIS 6) (Seidenkrantz, 1993a). A large amount of ice-rafted debris in the sediments shows that the initial marine stage was characterised by icebergs, calving from the retreating glacial ice front. The foraminifers indicate, as well as the stable-isotope data (Fig. 3), a glaciomarine environment where the mixing with the glacial meltwater caused a reduction in salinity.

The warming that caused the late Saalian ice retreat was further accentuated in the Zeifen interstadial (Seidenkrantz et al., 1996). During this warm interval, glacial melting increased, causing a high outflow of surface water from the palaeo-Kattegat/ Skagerrak. This increased outflow resulted in a bottom-water inflow of saline water from the Atlantic and in the establishment of a halocline, as known in the present-day Kattegat. Thus, instead of a decrease in salinity, the warming caused an increase in salinity at the sea bottom and allowed the immigration of species such as Astrononion gallowayi Loeblich \& Tappan and Stainforthia feylingi Knudsen \& Seidenkrantz, which require almost normal-marine conditions. This type of species is grouped as a whole as 'transitional' in Figure 3.

The interstadial warming was abruptly terminated by a short-term 'Younger Dryas-type' climate deterioration, the Kattegat stadial, during which conditions similar to those that existed before the interstadial were re-established (Seidenkrantz, 1993a). The water column was no longer stratified and the mixing of the waters caused a decrease in bottom-water salinity. Conditions gradually improved again and the stratification was restored, giving rise to increased bottomwater salinity and to the re-immigration of 'transitional' species at the end of the Saalian.

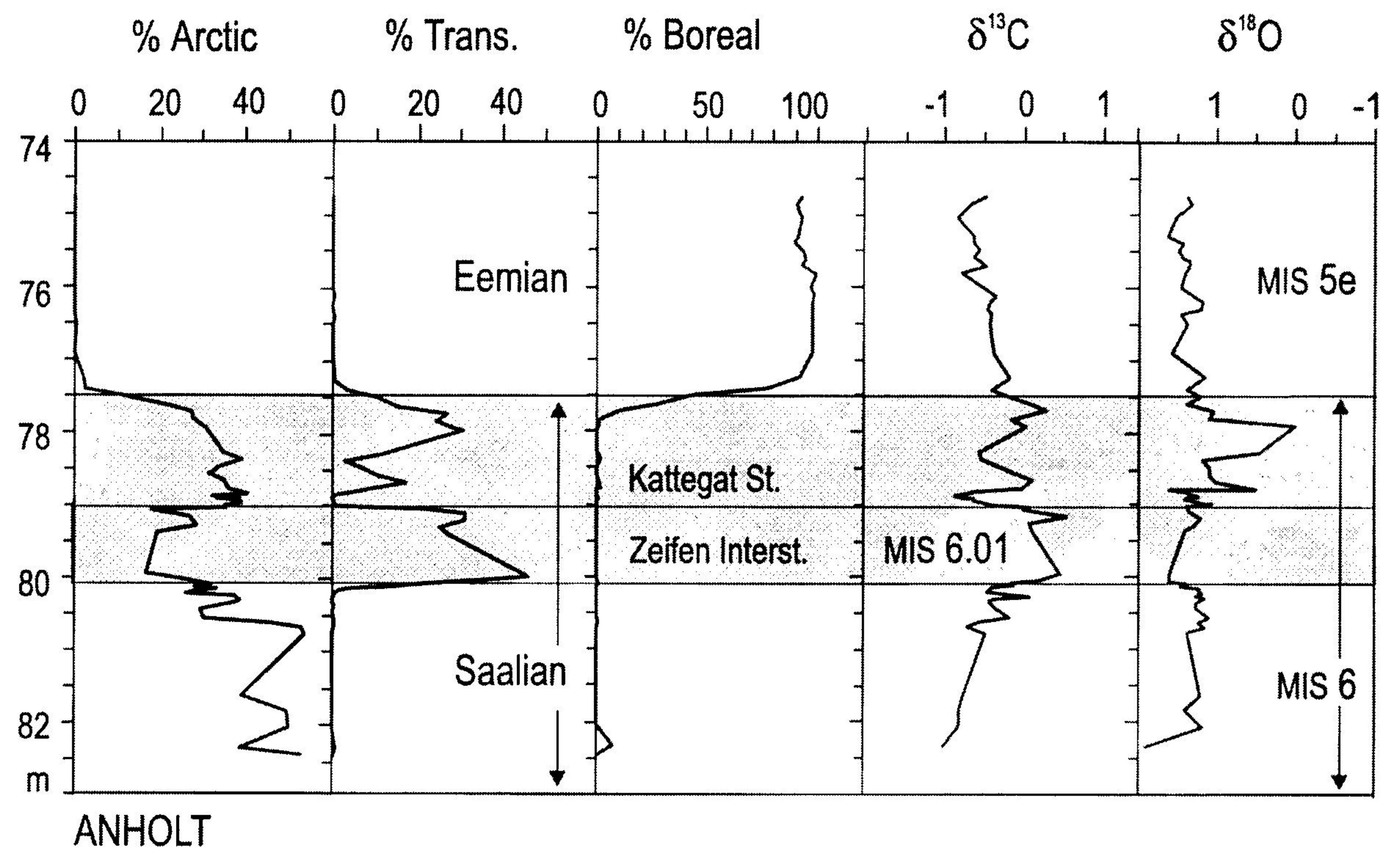

Fig. 3. Late Saalian and Eemian foraminiferal data and stable isotopes from Anholt. 'Arctic', 'transitional' and 'boreal' (including lusitanian) benthic species are grouped according to Seidenkrantz \& Knudsen (1997) and shown as percentages of the total benthic foraminiferal fauna. The benthic stable-isotope values have been normalised to sea water partly using the calculations by Poole (1994).

Trans. $=$ transitional benthic species. 
The faunal development in the late Saalian is comparable to that described from the late Weichselian at Skagen, where similar fluctuations in meltwater runoff caused stratification of the water column during the Bølling and the Allerød and mixing during the Older Dryas and the Younger Dryas (Knudsen et al., 1996). Contrary to the Allerød-Younger Dryas event that seems to have mainly influenced the northern hemisphere, the Zeifen-Kattegat climate fluctuation (here correlated with MIS event 6.01; see Pisias et al., 1984) has in recent years been recognised, however, in a number of both terrestrial and deep-sea records. This shows that it presumably influenced the ocean circulation and had a global impact (Seidenkrantz et al., 1996).

The oxygen-isotope record (Fig. 3) indicates two phases of significant meltwater runoff during the Kattegat stadial. These may be due to the drainage of a late Saalian ice-dammed lake, corresponding to the drainage of the Baltic Lake at the end of the Weichselian. The changes in oxygen isotopes would suggest a drop in salinity of $2.3 \%$ at the peak of the events (see below).

\section{Eemian temperatures and climatic fluctuations}

Foraminiferal faunal characteristics in the high-resolution late Saalian-Eemian-early Weichselian successions at Skagen and Nørre Lyngby, North Jutland (Fig. 1), are shown in Figures 4 and 5. As found in the Anholt cores, the change from an arctic to a warm temperate composition of fauna seems to have been relatively fast at the glacial/interglacial transition (e.g., Knudsen et al., in press).

The Eemian sediments in the entire North Jutland region, as well as on the island of Anholt, generally contain warm temperate foraminiferal faunas with the same lusitanian (warm temperate) contents as described above from Apholm and Skærumhede, indicating water temperatures a few degrees higher than at present. This interpretation is supported by temperature calculations based on the stable oxygen isotopes (Fig. 5), which give an average bottom-water temperature of approx $6^{\circ} \mathrm{C}$ (maximum $6.7^{\circ} \mathrm{C}$ ) during the warm intervals of the Eemian compared to a present temperature of about $5^{\circ} \mathrm{C}$ at $300 \mathrm{~m}$ water depth (Svansson, 1975) (300 $\mathrm{m}$ is the interpreted approximate water depth at Skagen during the Eemian).

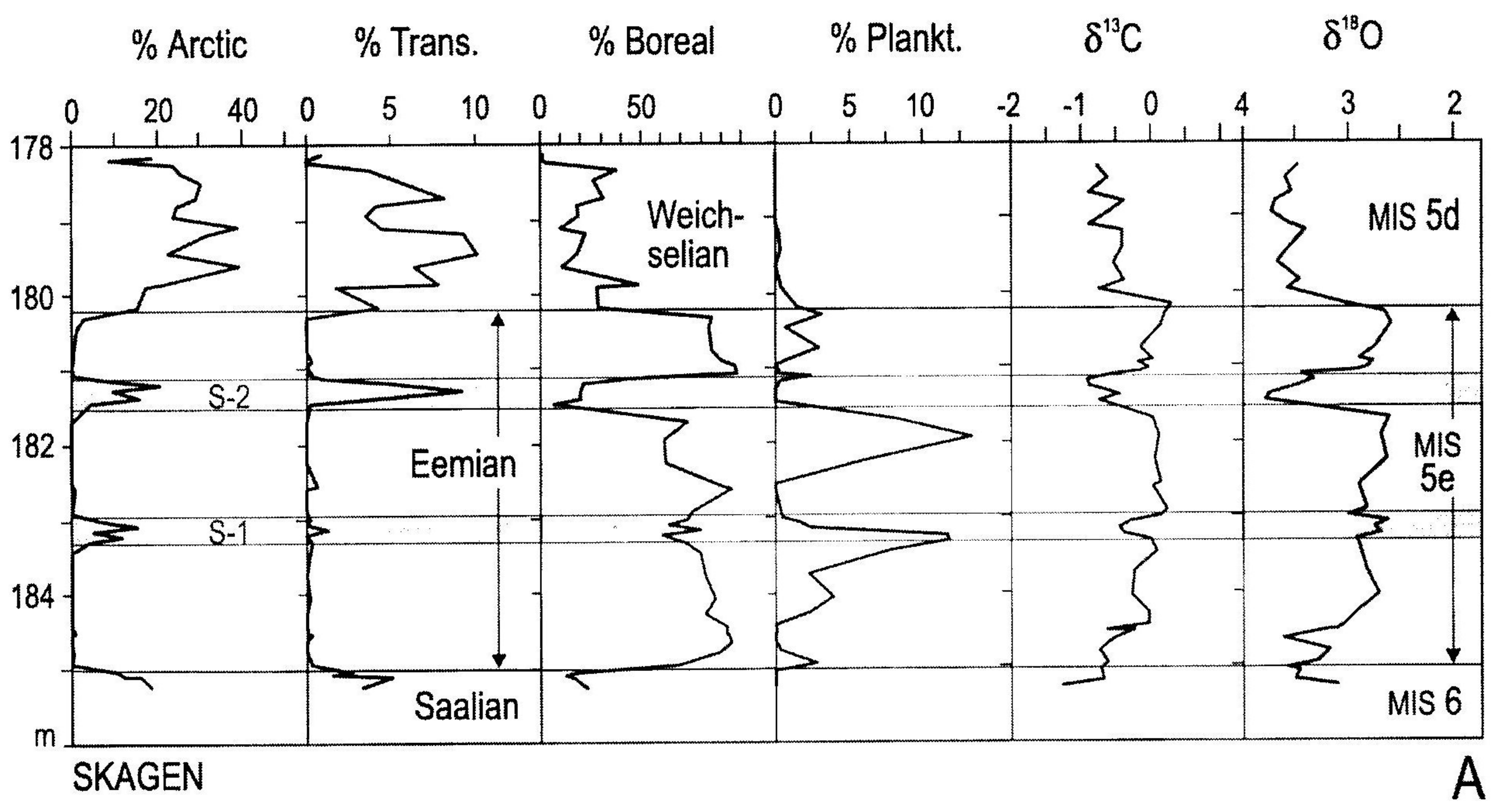

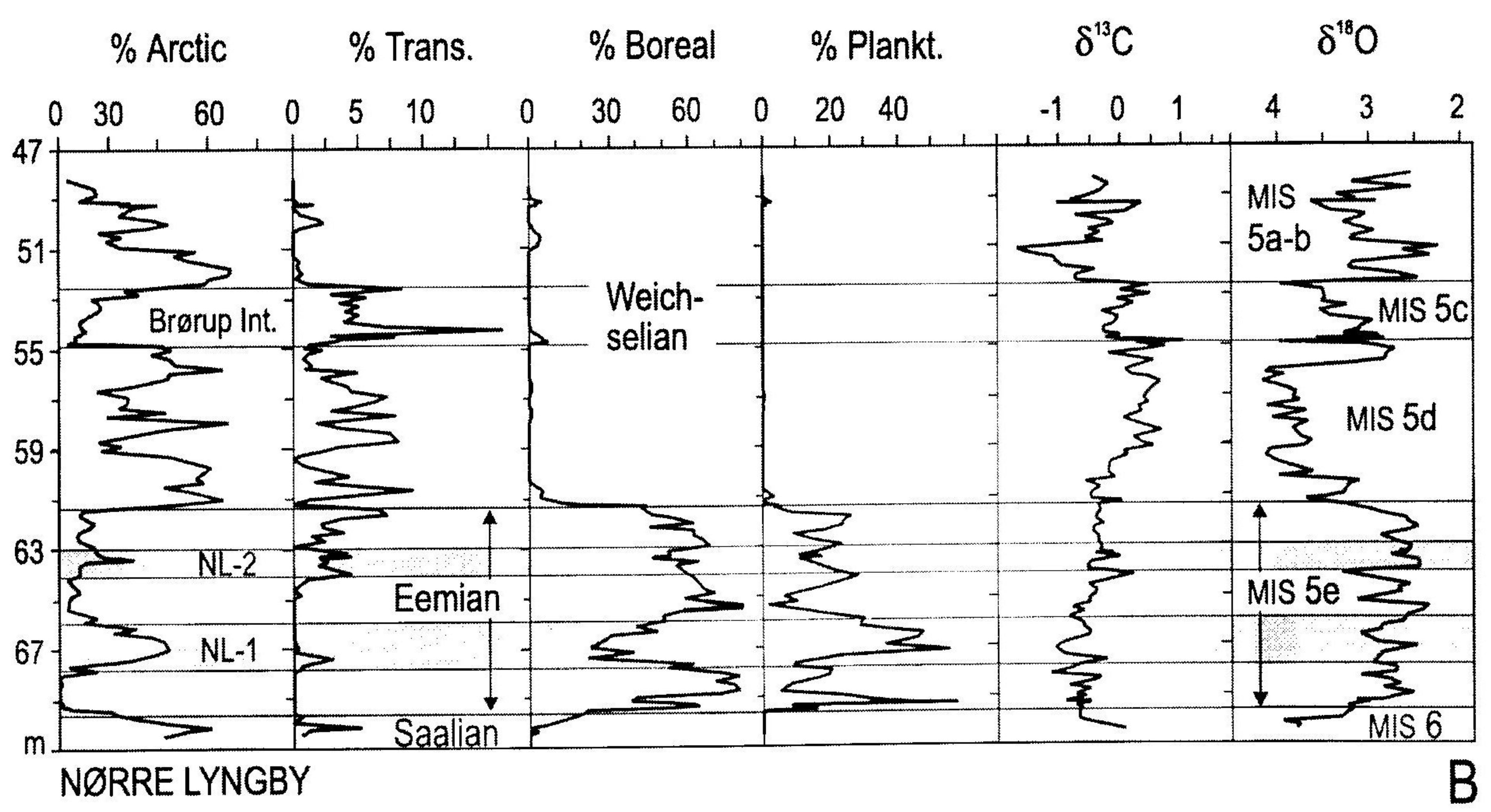

Fig. 4. Late Saalian, Eemian and early Weichselian foraminiferal assemblages and stable isotopes from Skagen (4A) and Nørre Lyngby (4B). 'Arctic', 'transitional' and 'boreal' (including lusitanian) benthic species are grouped according to Seidenkrantz \& Knudsen (1997) and shown as percentages of the total benthic foraminiferal fauna. The benthic stable-isotope values have been normalised to sea water partly using the calculation by Poole (1994). The intervals $S-1$ and S-2, as well as NL-1 and NL-2, respectively, indicate cooling periods within the Eemian.

Trans. = transitional benthic species; Plankt. $=$ planktonic foraminifers. 


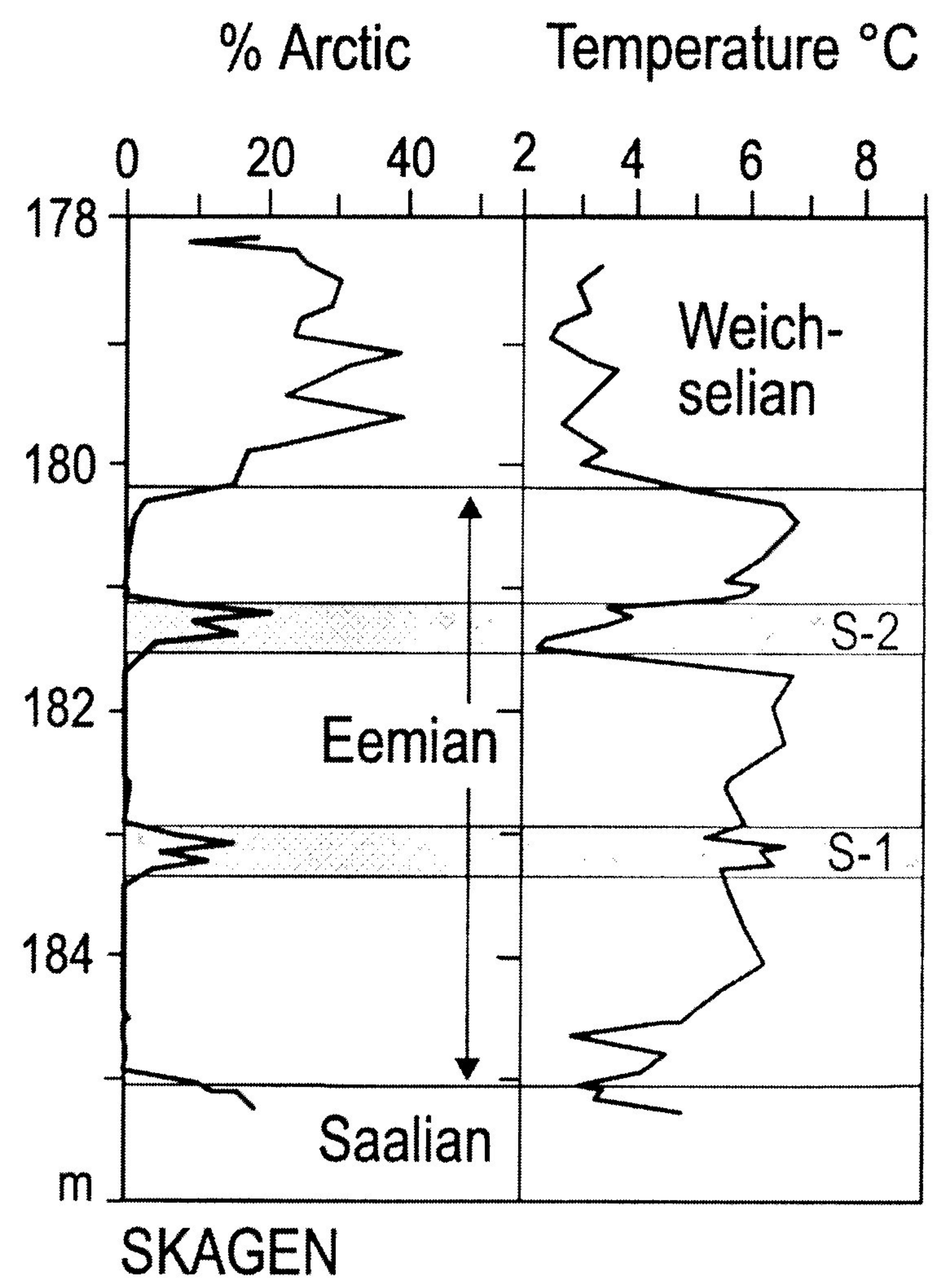

Fig. 5. Bottom-water temperatures through the late Saalian, Eemian and early Weichselian at Skagen. The temperatures are calculated on the basis of the benthic $\delta^{18} \mathrm{O}$ record with the assumption of a constant bottom water salinity of $35 \%$ at the site. Equations of Craig \& Gordon (1965) and Shackleton (1974) have been used.

The calculation of the palaeotemperature changes at Skagen (Fig. 5) is based on the assumption that the Eemian salinity at the site was the same as today at $300 \mathrm{~m}$ depth on the southern flank of the Norwegian Trench (see Svansson, 1975; Rohde, 1987) throughout the interglacial (see also below). In this part of the Skagerrak, the present salinity is nearly constant throughout the year and the mean salinity reaches $35 \%$, with a standard deviation of less than $0.1 \%$ (Rodhe, 1987).

The foraminiferal faunas at Skagen and at Nørre Lyngby (Fig. 4) show a number of significant changes through the Eemian. Most of the minor variations are presumably due to changes in the inflow of the Jutland Current and in the inflow of deep Atlantic water along the southern margin of the Norwegian Trench. In addition, however, two major cooling episodes with complete faunal changes from the boreal-lusitanian to arctic-subarctic faunas are seen at both Skagen and Nørre Lyngby (S-1, S-2: Figs. 4A and 5; NL-1, NL-2: Fig. 4B) (Seidenkrantz et al., 1995; Seidenkrantz \& Knudsen, 1997; Kristensen et al., 1998).

The former cooling (S-1) is considerably less pronounced at Skagen than at Nørre Lyngby, where the first cooling (NL-1) was clearly more serious and presumably covered a longer time-span than the second
(NL-2). This difference may be explained by short periods of non-deposition and/or even erosion at specific levels at both sites. Similar temperature changes are not registered at Skærumhede, Apholm and Anholt.

At Skagen, the changes in the benthic foraminiferal fauna were followed by shifts in the stable-isotope record (Figs. 4, 5). The $\delta^{13} \mathrm{C}$-values show that the two cold events were accompanied by changes in the water masses, and a marked shift in the $\delta^{18} \mathrm{O}$-values during the second cold event (S-2) also indicates a significant cooling, possibly coinciding with an increase in salinity. If the salinity remained constant, the shift in oxygen isotopes would indicate a drop in water temperature of nearly $4.5^{\circ} \mathrm{C}$ (Fig. 5). We are aware, however, of the possibility of salinity changes in connection to colder phases.

Marine Eemian records from the Western Baltic area suggest that considerably higher salinities occurred in the area, at least during the first few thousands of years of the Eemian (see above). A similar general higher salinity in the Kattegat/Skagerrak area during this interval of free interchange of seawater through the Baltic would change our temperature calculations to even higher values than the $6^{\circ} \mathrm{C}$ as found for the early Eemian (see Fig. 5). This would actually bring the bottom-water temperature profile through the Eemian into better accordance with the temperature indications from pollen in the same area, which suggest that the Eemian optimum occured within the first 3000 years of the interglacial (Zagwijn, 1996; Björck et al., 2000).

The occurrence of a relatively high number of planktonic foraminifers, mainly consisting of polar and subpolar species, in part of the Eemian at both Skagen and Nørre Lyngby (Fig. 4), indicates a higher influx of oceanic water than today. Even at Apholm, there is a considerable content of planktonic specimens during a short time interval (Fig. 2). Only few planktonic foraminifers were found from the Holocene optimum at Skagen, and these all belong to boreal species (Seidenkrantz \& Knudsen, 1997). Today, boreal planktonic foraminifers occur only in small numbers in the westernmost part of Skagerrak, and polar and subpolar species are not present at all (Seidenkrantz, 1993b).

It is assumed that the polar and subpolar planktonic foraminifers were transported to this area from the Atlantic during the Eemian. This is also supported by the fact that the highest contents of planktonic specimens are found at Nørre Lyngby, which is closest to the open ocean, while the amount successively decreases further to the south-east in the Kattegat Depression towards Anholt, where no planktonic 
foraminifers are present. The amount of planktonic foraminifers is thus considered as a measure of a increased inflow of oceanic waters into the area during the Eemian.

The Eemian termination is reflected by a relatively abrupt change from warm temperate to subarctic and arctic benthic faunas and by a concurrent decrease in water depth both at Skagen and Nørre Lyngby. The duration of the transition was estimated by Knudsen et al. (in press) to have been 500-700 years. The Early Weichselian Brørup interstadial has been recorded in the marine environment at Nørre Lyngby (Fig. 4B) (Kristensen et al., 1998).
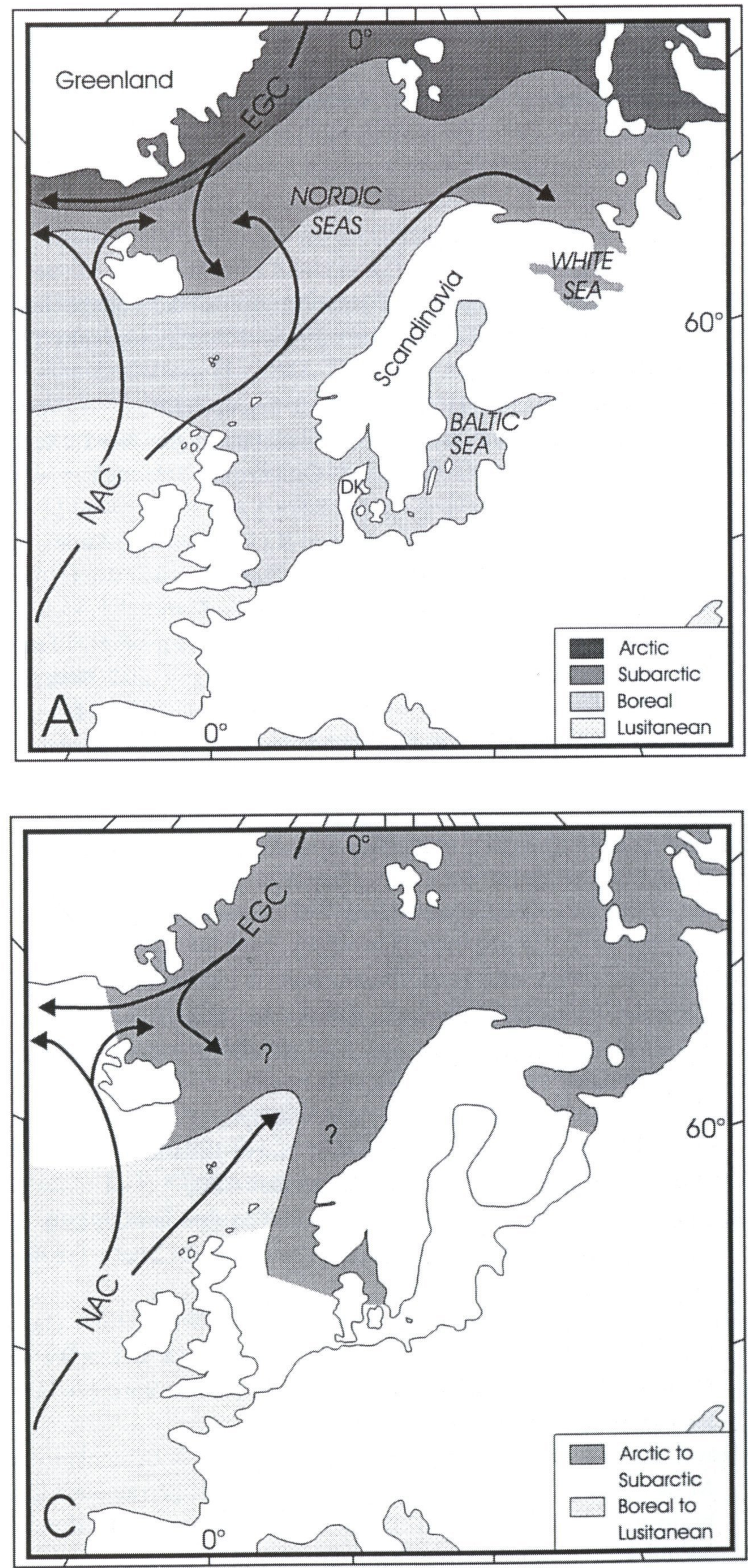

\section{Eemian palaeoceanography}

Today, the North Atlantic Current carries warm water along the coasts of Western Europe, allowing the establishment of a lusitanian (warm temperate) fauna along the west coasts of France and the British Isles (Fig. 6A). The current is gradually mixed with the colder surface waters in the northern North Atlantic and it is neither strong enough nor warm enough at present to allow the lusitanian fauna to pass north of Scotland and into the North Sea. Hence, the present North Sea area is characterised by a boreal (cooltemperate) fauna.

During most of the Eemian, i.e., the warmer parts,

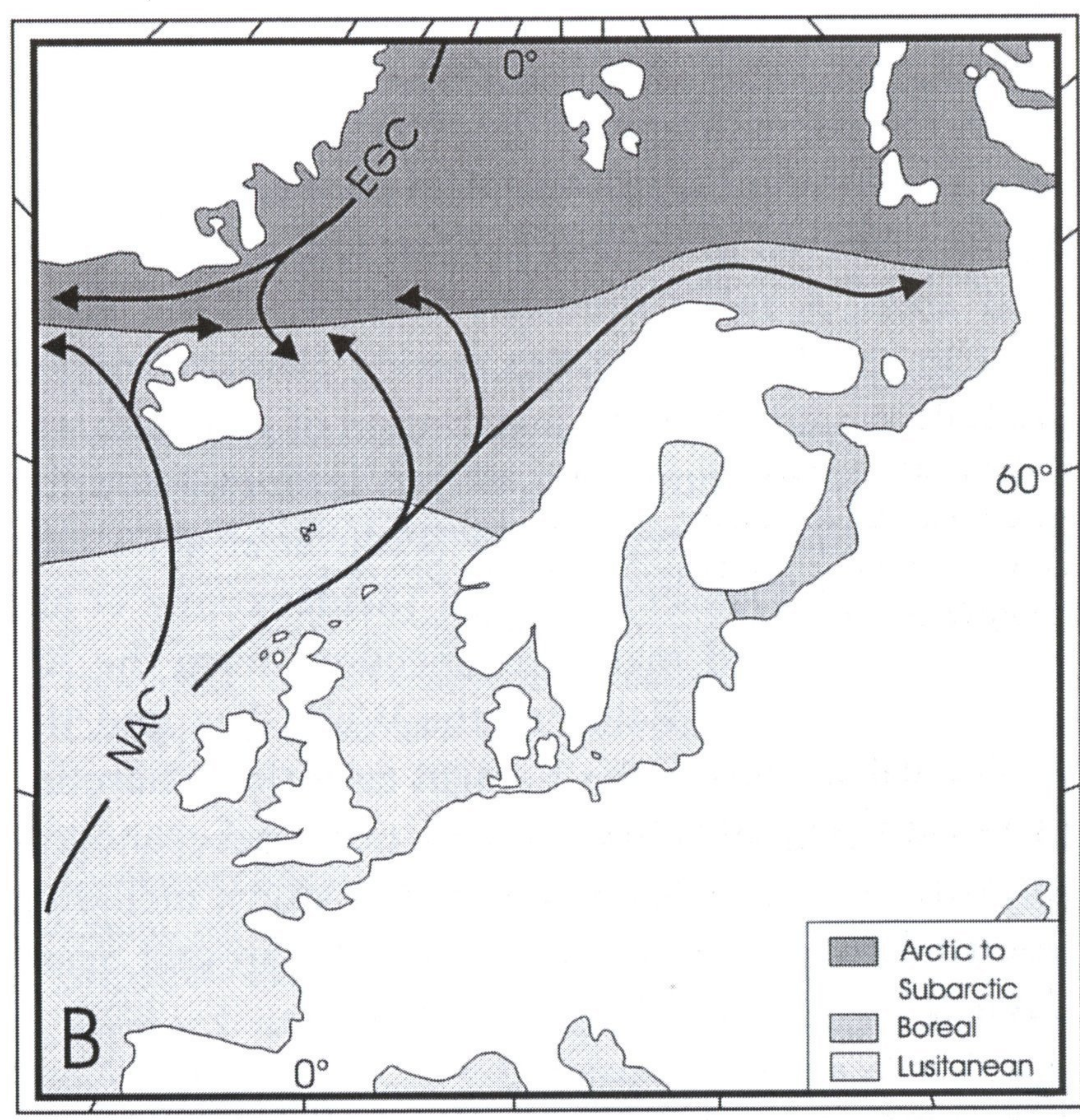

Fig. 6. Faunal provinces. The extension of the maximum Eemian transgression (maps B and C) is suggested for Scandinavia, the Baltic area and Western Russia (after Donner, 1995; Seidenkrantz \& Knudsen, 1997). Areas with insufficient knowledge about climate stability in the Eemian are marked as white.

A: Modern (after Feyling-Hanssen, 1955).

B: Eemian optimum (partly after Sejrup, in Seidenkrantz \& Knudsen, 1994).

C: Eemian cold events (partly after Fronval et al., 1998; also in Knudsen et al., in press).

NAC $=$ North Atlantic Current; EGC = East Greenland Current; DK $=$ Denmark. 
the North Atlantic Current was presumably stronger than today (Weaver \& Hughes, 1994). Lusitanian faunas were established in the entire North Sea region, including along the coasts of southern Norway (Fig. 6B). In Denmark, the Eemian influx of warmer water into the North Sea is reflected in both the shallowwater assemblages to the south and the deeper-water faunas to the North. The Eemian benthic foraminiferal assemblages thus contain several species that do not live in the area today, but belong in warmer waters along the Atlantic margin of Europe or in the Mediterranean.

Studies from the Greenland, Iceland and Norwegian Seas (the Nordic seas) indicate that the North Atlantic Current presumably had a more westerly direction during the Eemian than today (Larsen et al., 1995; Fronval et al., 1998; Bauch et al., 1999). Changes in the strength and/or the direction of the North Atlantic Current may also explain the Eemian cooling phases observed in the Nordic seas and in the Danish shelf areas. A more southerly location of the arctic front in the Norwegian Sea during Eemian cooling intervals would allow the penetration of subarctic waters towards the south (Fig. 6C) as indicated both by data from the Norwegian Sea (Fronval et al., 1998) and from the Danish shelf area (Seidenkrantz et al., 1995). Short-lived marine connections from the Atlantic through the Baltic to the White Sea and the Arctic Ocean during the Eemian might also have influenced the eastern North Atlantic palaeoceanography, but this problem needs further study, including modelling of the Eemian oceanography around Scandinavia.

\section{References}

Adkins, J.F., Boyle, E.A., Keigwin, L. \& Cortijo, E., 1997. Variability of the North Atlantic thermohaline circulation during the last interglacial period. Nature 390: 154-156.

Bauch, H.A., Erlenkeuser, H., Fahl, K., Spielhagen, R.F., Weinelt, M.S., Andruleit, H. \& Henrich, R., 1999. Evidence for a steeper Eemian than Holocene sea surface temperature gradient between Arctic and sub-Arctic regions. Palaeogeography Palaeoclimatology Palaeoecology 144: 95-117.

Behre, K.-E., Menke, B. \& Streif, H., 1979. The Quaternary geological development of the German part of the North Sea. In: Oele, E., Schüttenhelm, R.T.E. \& Wiggers, A.J. (eds.): The Quaternary history of the North Sea. Acta Universitatis Upsaliensis, Symposia Universitatis Upsaliensis Annum Quingentesimum Celebrantis (Uppsala) 2: 85-113.

Björck, S., Noe-Nygaard, N., Wollin, J., Houmark-Nielsen, M., Hansen, H.J. \& Snowball, I., 2000. Eemian lake development, hydrology and climate - a multi-stratigraphic study of the Hollerup site in Denmark. Quaternary Science Reviews 19: 509-536.

Chapell, J. \& Shackleton, N.J., 1986. Oxygen isotopes and sea level. Nature 324: 137-140.

CPM (CLIMAP Project Members), 1984. The last interglacial ocean. Quaternary Research 21: 123-224.

Craig, H. \& Gordon, L.I., 1965. Deuterium and oxygen 18 variations in the ocean and the marine atmosphere. In: Tongiorgi, E. (ed.): Stable isotopes in oceanographic studies and Paleotemperatures. Consigilo Nazionale Delle Ricerche, Laboratorio di Geologia Nucleare (Pisa): 9-130.

Dansgaard, W., Johnsen, S.J., Clausen, H.B., Dahl-Jensen, D., Gundestrup, N.S., Hammer, C.U., Hvidbjerg, C.S., Steffensen, J.P., Sveinbjörnsdóttir, A.E., Jouzel, J. \& Bond, G., 1993. Evidence for general instability of past climate from a $250-\mathrm{kyr}$ ice core record. Nature 364: 218-220.

Donner, J., 1995. The Quaternary history of Scandinavia. Cambridge University Press (Cambridge): 200 pp.

Feyling-Hanssen, R.W., 1955. Stratigraphy of the marine LatePleistocene of Billefjorden, Vestspitsbergen. Norsk Polarinstitutt Skrifter 107: 1-186.

Field, M.H., Huntley, B. \& Müller, H., 1994. Eemian climate fluctuations observed in a European pollen record. Nature 371: 779783.

Forsström, L., Aalto, M., Eronen, M. \& Grönlund, T., 1988. Stratigraphical evidence for Eemian crustal movements and relative sea-level changes in eastern Fennoscandia. Palaeogeography Palaeoclimatology Palaeoecology 68: 317-335.

Fronval, T. \& Jansen E., 1996. Rapid changes in ocean circulation and heat flux in the Nordic seas during the last interglacial period. Nature 383: 806-810.

Fronval, T. \& Jansen E., 1997. Eemian and early Weichselian (140$60 \mathrm{ka})$ paleoceanography and paleoclimate in the Nordic seas with comparisons to Holocene conditions. Paleoceanography 12: 443-462.

Fronval, T., Jansen, E., Haflidason, H. \& Sejrup, H.P., 1998. Variability in surface and deep water conditions in the Nordic seas during the Last Interglacial period. Quaternary Science Reviews 17: 963-985.

Gallup, C.D., Edwards, R.L. \& Johnson, R.G., 1994. The timing of high sea levels over the past 200,000 years. Science 263: 796800.

Glaister, C.G. \& Gibbard, P.L., 1998. Pollen stratigraphy of Late Pleistocene marine sediments at Nørre Lyngby and Skagen, North Denmark. Quaternary Science Reviews 17: 839-854.

GRIP Members, 1993. Climate instability during the last interglacial period recorded in the GRIP ice core. Nature 364: 203207.

Jessen, K. \& Milthers, V., 1928. Stratigraphical and paleontological studies of interglacial fresh-water deposits in Jutland and Northwest Germany. Geological Survey of Denmark, II Series 48: 1379.

Johnsen, S.J., Clausen, H.B., Dansgaard, W., Gundestrup, N.S., Hammer, C.U. \& Tauber, H., 1995. The Eem stable isotope record along the GRIP ice core and its interpretation. Quaternary Research 43: 117-124.

Knudsen, K.L., 1984. Foraminiferal stratigraphy in a marine Eemian-Weichselian sequence at Apholm, North Jutland. Bulletin of the Geological Society of Denmark 32: 169-180.

Knudsen, K.L., 1985. Foraminiferal faunas in Eemian deposits of the Oldenbüttel area, Nord-Ostsee-Kanal (Kiel Canal). Geologisches Jahrbuch A 86: 27-47.

Knudsen, K.L., 1992. A long marine Eemian-Weichselian shelf record in North Denmark, Scandinavia. In: Kukla, G.J. \& Went, E. (eds.): Start of a glacial. NATO ASI Series I 3. Springer-Verlag (Berlin-Heidelberg): 157-171.

Knudsen, K.L., Conradsen, K., Heier-Nielsen, S. \& Seidenkrantz, M.-S., 1996. Palaeoenvironments in the Skagerrak-Kattegat basin in the eastern North Sea during the deglaciation. Boreas 25: $65-77$. 
Knudsen, K.L. \& Lykke-Andersen, A.-L., 1982. Foraminifera in Late Saalian, Eemian, Early and Middle Weichselian of the Skærumhede I boring. Bulletin of the Geological Society of Denmark 30: 97-109.

Knudsen, K.L., Seidenkrantz, M.-S. \& Kristensen, P. (in press). The northern North Atlantic circulation during the last interglacial and Early Glacial. Quaternary Research.

Konradi, P.B., 1976. Foraminifera in Eemian deposits at Stensigmose, southern Jutland. Geological Survey of Denmark, II Series 105: 1-57.

Kosack, B. \& Lange, W., 1985. Das Eem-Vorkommen von Offenbüttel/Schnittlohe und die Ausbreitung des Eem-Meeres zwischen Nord- und Ostsee. Geologisches Jahrbuch A 86: 3-17.

Kristensen, P., Gibbard, P., Knudsen, K.L. \& Ehlers, J. (in press). Last interglacial stratigraphy at Ristinge Klint, South Denmark. Boreas 29.

Kristensen, P., Knudsen, K.L., Lykke-Andersen, H., Nørmark, E., Peacock, J.D. \& Sinnoth, A., 1998. Interglacial and glacial climate oscillations in a marine shelf sequence from northern Denmark - a multidisciplinary study. Quaternary Science Reviews 17: 813-837.

Krog, H., 1979. Late Pleistocene and Holocene shorelines in western Denmark. In: Oele, E., Schüttenhelm, R.T.E. \& Wiggers, A.J. (eds.): The Quaternary history of the North Sea. Acta Universitatis Upsaliensis, Symposia Universitatis Upsaliensis Annum Quingentesimum Celebrantis (Uppsala) 2: 75-83.

Larsen, E,. Sejrup, H.P., Johnsen, S.J. \& Knudsen, K.L., 1995. Do Greenland ice cores reflect NW European interglacial climate variations? Quaternary Research 43: 125-132.

Lykke-Andersen, H., 1987. Thickness of Quaternary deposits and their relation to the pre-Quaternary in the Fennoscandian border zone in Kattegat and Vendsyssel. Boreas 16:369-371.

Lykke-Andersen, H., Knudsen, K.L. \& Christensen, C., 1993. The Quaternary of the Kattegat area, Scandinavia: a review. Boreas 22: 269-281.

McManus, J.F., Bond, G.C., Broecker, W.S., Johnsen, S., Labeyrie, L. \& Higgins, S., 1994. High-resolution climate records from the North Atlantic during the last interglacial. Nature 371: 326-329.

Nordmann, V., 1928. La position stratigraphique des dépots d'Eem. Geological Survey of Denmark, II Series 47:1-81.

Penney, D.N., 1989. Microfossils (Foraminifera, Ostracoda) from an Eemian (last interglacial) tidal flat in south-west Denmark. Quaternary International 3/4: 85-91.

Pisias, N.G., Martinson, D.G., Moore, T.C. Jr., Shackleton, N.J., Prell, W., Hays, J. \& Boden, G., 1984. High resolution stratigraphic correlation of benthic oxygen isotope records spanning the last 300,000 years. Marine Geology 56: 119-136.

Poole, D.A.R., 1994. Neogene and Quaternary palaeoenvironment on the north Norwegian shelf. Unpublished Ph.D. thesis University of Tromsø: $141 \mathrm{pp}$.

Raukas, A., 1991. Eemian interglacial record in the northwestern European part of the Soviet Union. Quaternary International 10/12: 183-189.

Rohde, J., 1987. The large-scale circulation in the Skagerrak; interpretation of some observations. Tellus 39A: 245-253.
Seidenkrantz, M.-S., 1993a. Benthic foraminiferal and stable isotope evidence for a "Younger Dryas-style" cold spell at the Saalian-Eemian transition, Denmark. Palaeogeography Palaeoclimatology Palaeoecology 102: 103-120.

Seidenkrantz, M.-S., 1993b. Subrecent changes in the foraminiferal distribution in the Kattegat and the Skagerrak, Scandinavia: anthropogenic influence and natural causes. Boreas 22: 383-395.

Seidenkrantz, M.-S., Bornmalm, L., Johnsen, S.J., Knudsen, K.L., Kuijpers, A., Lauritzen, S.-E., Leroy, S.A.G., Mergeal, I., Schwegeer, C. \& Van Vliet-Lanoë, B., 1996. Two-step deglaciation at the oxygen isotope stage 6/5e transition: the Zeifen-Kattekat climate oscillation. Quaternary Science Reviews 15: 63-75.

Seidenkrantz, M.-S. \& Knudsen, K.L., 1994. Marine high resolution records of the last interglacial in Northwest Europe: a review. Géographie Physique et Quaternaire 48: 157-168.

Seidenkrantz, M.-S. \& Knudsen, K.L., 1997. Eemian climatic and hydrographical instability on a marine shelf in Northern Denmark. Quaternary Research 47: 218-234.

Seidenkrantz, M.-S., Kristensen, P. \& Knudsen, K.L., 1995. Marine evidence for climatic instability during the last interglacial in shelf records from northwest Europe. Journal of Quaternary Science 10: 77-82.

Sejrup, J.P. \& Knudsen, K.L., 1999. Geochronology and palaeoenvironment of marine Quaternary deposits in Denmark; new evidence from northern Jutland. Geological Magazine 136: 561578.

Sejrup, H.P. \& Larsen, E., 1991. Eemian-Early Weichselian N-S temperature gradients; North Atlantic-NW Europe. Quaternary International 10/12: 161-166.

Shackleton, N.J., 1974. Attainment of isotopic equilibrium between ocean water and the benthonic Foraminifera genus Uvigerina: isotopic changes in the ocean during the last glacial. In: Labeyrie, L. (ed.): Variation du climat au cours du|Pleistocène. Colloques Internationaux du Centre Nationale de la Recherche Scientifique 219: 203-209.

Shackleton, N.J., 1987. Oxygen isotopes, ice volume and sea level. Quaternary Science Reviews 6: 183-190.

Svansson, A., 1975. Physical and chemical oceanography of the Skagerrak and the Kattegat I: Open sea conditions. Fishery Board of Sweden, Institute of Marine Research Report 1: 88 pp.

Van Voorthuysen, J.H., 1957. Foraminiferen aus dem Eemian (Riss-Würm Interglacial) in der Bohrung Amersfoort I (locus typicus). Mededelingen van de Geologische Stichting, Nieuwe Serie 11:27-39.

Weaver, A.J. \& Hughes, T.M.C., 1994. Rapid interglacial climate fluctuation driven by North Atlantic ocean circulation. Nature 367: 447-450.

Zagwijn, W.H., 1986. The Pleistocene of The Netherlands with special reference to glaciation and terrace formation. Quaternary Science Reviews 5: 341-345.

Zagwijn, W.H., 1996. An analysis of Eemian climate in Western and central Europe. Quaternary Science Reviews 15: 451-469.

Zans, V., 1936. Das letztinterglaziale Portlandia-Meer des Balticums. Bulletin de la Commission Géologique de Finlande 115: 231-250. 